\title{
Seed predation by mammals in forest fragments in Monteverde, Costa Rica
}

\author{
Federico A. Chinchilla \\ Instituto de Ecología, Universidad Nacional Autónoma de México, 70-275, México D.F. México. Current address: \\ Estación Biológica Monteverde, Apdo. 22-5655, Costa Rica; federicocr@costarricense.cr
}

Received 20-XI-2008. Corrected 15-I-2009. Accepted 12-II-2009.

\begin{abstract}
Few studies have evaluated seed predation in fragmented landscapes, in which lower species diversity is expected to modifying ecological interactions. The rates of seed removal by mammals were investigated in a continuous forest and two fragmented patches of Premontane Tropical Moist Forest, in Monteverde, Costa Rica. The composition of mammalian seed-predators in each site was recorded during 16 months. The removal of four native tree species of experimental seeds: Ocotea valeriana and Ocotea whitei (Lauraceae), Panopsis costaricensis (Proteaceae) and Billia colombiana (Hippocastanaceae) in forest understories was followed during two annual fruiting seasons for each species. Results indicated similar species composition of seed-predators between continuous forest, the largest fragment (350 ha). However the smaller fragment (20 ha), had fewer seed predators. In this fragment, the specialized seed predator Heteromys desmarestianus (Rodentia) was more abundant. Unexpectedly, seed-predation in the two forest fragments and the continuous forest did not differ statistically for any of the seed species. Apparently, the higher abundance of small seed-predators in the fragments was compensated by the absence of medium and large seed-predators, like Agouti paca, Dasyprocta punctata (both Rodentia) and Pecari tajacu (Artiodactyla) recorded in continuous forest. Removal of experimentally-placed seeds was higher when the number of naturally occurring seeds in the sites was lower. This result could best be attributed to differential satiation of seed predators rather than differences in richness or abundance of seed predators. Rev. Biol. Trop. 57 (3): 865-877. Epub 2009 September 30.
\end{abstract}

Key words: seed removal, seed predators, forest fragmentation, predator satiation.

Tropical communities are among the most diverse and less studied biological systems, that currently are being modified and cleared (Wright 2005), causing forest fragmentation, environmental changes, and generalized species loss (Saunders et al. 1991, Murcia 1995, Laurance and Bierregaard 1997, Didham et al. 1998, Chiarello 1999, Ruiz 2003). But forest fragmentation also means changes in animalplant interactions, such as herbivory, frugivory, pollination, seed dispersal, trampling of seedlings and seed predation, among many others (Dirzo and Miranda 1991, Terborgh and Wright 1994, Ferreira and Laurance 1997, Phillips 1997, Cascante 1998, Rao et al. 2001, Roldán and Simonetti 2001, Kitamura and Yumoto 2002, Dirzo et al. 2007). These interactions can be expected to be changing because lower species richness in fragmented landscapes may modify more than just forest structure and species diversity.

In Costa Rica, Premontane Tropical Moist Forest life zone is considered an endangered ecosystem, because only $12.8 \%$ of its total area is protected in reserves (Nadkarni and Wheelwright 2000, Sánchez-Azofeifa et al. 2003). Outside reserves and national parks, this life zone is present in fragmented landscapes, which increases the conservation value of the remnants (Guindon 1997). Although the patterns of species richness and diversity are well documented in forest fragments, the effects of fragmentation on ecological interactions are poorly understood (Wright 2003, Fleury and 
Galetti 2006, Dirzo and Mendoza 2007, Wright et al. 2007). In this study the mammalian seed removal in fragmented and continuous forests in this life zone was evaluated.

\section{MATERIALS AND METHODS}

Study site: Monteverde $\left(10^{\circ} 18^{\prime} \mathrm{N}\right.$, $\left.84^{\circ} 48^{\prime} \mathrm{W}\right)$, in the Cordillera de Tilarán, Costa Rica. The study include three different forested sites: one continuous forest area at the Monteverde Biological Station (EBM, at 1460 $\mathrm{m}$ of elevation) directly connected to an intact expanse of 55000 forested hectares, and two forest fragments, with 350 and 20 hectares, hereafter referred to as CAT (elevation 1250 $\mathrm{m}$ ) and FAR (elevation $1400 \mathrm{~m}$ ) respectively. These three sites belong to the Premontane Tropical Moist Forest life zone (Tosi 1969). These study sites are private properties. The two forest fragments are surrounded by dairy pastures, and were fenced more than 10 years ago to prevent cattle from entering. These fragments were created 40 to 55 years ago according to the respective owners, when the environs were transformed to cattle pastures. The forests within these fragments are older and mature.

Presence and relative abundance of mammalian seed predators: Presence and relative abundance of mammlian seed predators was assessed in the three sites from August 1999 to March 2001. To determine which small species were present, in each site one $70 \mathrm{~m} \times 70$ $\mathrm{m}$ (0.49 ha) trapping grid was used, containing 49 Sherman live traps, placed on the ground, one trap every $10 \mathrm{~m}$ in the grid. Each trap was baited with a mixture of raw rice, oats and vanilla. Trapps were placed once a month, three nights per site, for 16 months, during the darkest nights of each month. The sampling effort in each site was 2352 traps-night.

To evaluate the presence of larger species (more than $300 \mathrm{~g}$ ), the sites were surveyed by walking along two transects in each site per month, for ten months total. This consisted of walking through the forests along trails, during the morning and during early hours after dusk. Both diurnal and nocturnal species were observed and recorded, for a total sampling effort of 120 transect-hours. These transects were also performed on the darkest nights of each month. Mammal tracks were also recorded and identified in these transects, according to Aranda (1981) and Reid (1997).

To evaluate the relative abundance of mammalian seed predators, the criteria of Hayes and LaVal (1989) and Timm and LaVal (2000) was followed. For this study, a given species was considered "abundant" if it was recorded (observed and/or captured) one or more times in $80 \%$ of the visits to the site, as "common" if it was recorded in 40 to $80 \%$ of the visits, as "uncommon" if it was recorded in 10 to $40 \%$ of visits, and "rare" if it was recorded on fewer than $10 \%$ of visits. Visits included both, trapping and walking transects.

Selection of seeds: Fresh seeds of four native tree species in the Monteverde area were chosen: (1) Ocotea valeriana (Standley) W. Burger, its seeds are $65 \mathrm{~mm}$ long; (2) O. whitei Woodson, its seeds are $40 \mathrm{~mm}$ long, (both species in Lauraceae); (3) Panopsis costaricensis Stand. (Proteaceae), its seeds are $50 \mathrm{~mm}$ long; and (4) Billia colombiana (Hippocastanaceae), its seeds are $60 \mathrm{~mm}$ long, length measurements from Castro (1998) and Haber et al. (1996). These seed species were selected after finding them with rodent teeth marks during field observations.

To test seed consumption by some native mammals, clean seeds were offered, according to their specific fruit production periods, to different individuals of Desmarest's spiny pocket mouse (Heteromys desmarestianus), naked-footed mouse (Peromyscus mexicanus) and slender harvest mouse (Reithrodontomys gracilis) previously trapped. All mice were kept in captivity for no more than five hours, or until feeding activity was observed. Water was supplied ad libitum. Each rodent was released at the same point where it was trapped. These seeds were also observed being consumed by agoutis (Dasyprocta puncata), Neotropical red squirrels (Sciurus granatensis) and collared peccaries (Pecari tajacu) in the field during the study. 
Seeds predation experiments: These experiments considered all of the removed seeds as seeds that had been preyed upon. To assess differences in seed predation rates in each forest,12 plots were set up; six plots from which mammals were excluded and six plots in which mammals had free access. Plots were arranged in a paired design, there were six paired plots in each site. Each enclosure consisted of a rectangular cage of galvanized wire mesh of $2 \mathrm{~m} \mathrm{x}$ $1 \mathrm{~m} \times 0.9 \mathrm{~m}$ in height. The squares of the mesh measured $12.7 \mathrm{~mm} \times 12.7 \mathrm{~mm}$ and excluded all mammalian seed predators (modified from Terborgh and Wrigth 1994, and Roldán and Simonetti 2001). Adjacent control plots $2 \mathrm{~m}$ from the enclosure were also established, placing only PVC tubes at the corners of each $1 \mathrm{~m} \mathrm{x}$ $2 \mathrm{~m}$ rectangle. Each pair of plots (enclosure and control) were placed on relative level ground to minimize the probability that seeds would move by rolling downslope. Plots were scattered haphazardly in about 20 ha at each site. In the forest fragments, plots were located at least $50 \mathrm{~m}$ away from edges. At EBM, plots were located near the Jilguero and the Cariblancos trails, from $30 \mathrm{~m}$ to $200 \mathrm{~m}$ away from trails. The distance between plots ranged from 200 $\mathrm{m}$ to $300 \mathrm{~m}$.

During two annual fruiting periods, ripe fruits, of the four selected species, were collected from the ground and from trees with no visible evidence of damage. Fruits were taken from nearby forest sites rather than the study sites. In the laboratory, fruit pulp was removed from each seed, except for $P$. costaricensis. Seeds removed from whole fruits are common in nature, for example, Ocotea spp. cleaned seeds occur in the ground dispersed by resplendent quetzals, three-wattled bellbirds, barenecked umbrellabirds or black guans. To avoid invertebrates-infested seeds, all the seeds were briefly placed in a water container, and those that floated were discarded. Undamaged seeds were taken and labelled individually with numbers from 1 to 350 . Seeds to be placed in the field were selected using a random numbers table. Depending on the seed availability, seven or nine seeds per plot were included, in both enclosure and control plots. Experimental seeds were identified with a vertical, semiburied, labeled wooden spoon. The seeds in each plot were observed and counted every other day over four weeks, or until all the seeds disappeared from their original location. This experiment was repeated twice for each species of seed, using seeds of $O$. valeriana in April and May of 2000 and April of 2001; seeds of $O$. whitei in July of 2000 and June - July of 2001; seeds of $P$. costarricensis in September 2001 and September 2002; and seeds of B. colombiana in October 2000 and October 2001.

Data analysis: The treatment effect (enclosure or free acces plots at each site) on the remainder mean number of seeds per species was analyzed with analysis of variance tests, using Statgraphics 2.1 (Serrano and Vargas 1995). The proportion of seeds removed was transformed using Box-Cox's better transformation (Sokal and Rohlf 2003) to fit assumptions of parametric statistics.

\section{RESULTS}

Mammalian seed predators: Altogether, 15 species of mammals were recorded and considered as seed-predators (Table 1). Most species (13) were found in the continuous forest, followed by the large fragment ( 9 species), and the small fragment (4 species). All but one species (the collared peccary) were Rodentia. A list of all the species of mammals found, including the non seed-predators, is reported in Appendix 1. Six species, including the collared peccary, were found exclusively in the continuous forest. Only two species, the pygmy rice mouse (Oligoryzomys fulvescens) and the prehensile-tailed porcupine (Coendou mexicanus), were not recorded in continuous forest (Table 1).

Species found in two or three sites had different relative abundances in each site. For example, Desmarest's spiny pocket mouse $(H$. desmarestianus), a specialized seed predator, was uncommon in the continuous forest, but was common in the large fragment, and abundant in 
TABLE 1

Seed predators abundance ${ }^{l}$ found at each study site in Monteverde, Costa Rica

\begin{tabular}{|c|c|c|c|c|}
\hline Species & Continuous & Fragment & Fragment & Presence \\
\hline & Forest & CAT & FAR & evidence \\
\hline Peromyscus mexicanus & A & A & A & Traps \\
\hline Scotinomys teguina & $\mathrm{C}$ & & & Traps \\
\hline Oryzomys albigularis & $\mathrm{U}$ & & & Traps \\
\hline Oryzomys alfaroi (group) & $\mathrm{R}$ & $\mathrm{R}$ & & Traps \\
\hline Oligoryzomys fulvescens & $\mathrm{R}$ & & & Traps \\
\hline Nyctomys sumichrasti & $\mathrm{R}$ & & & Traps \\
\hline Tylomys watsoni & $\mathrm{R}$ & & & Traps \\
\hline Heteromys desmarestianus & $\mathrm{U}$ & $\mathrm{C}$ & A & Traps \\
\hline Reithrodontomys gracilis & $\mathrm{C}$ & $\mathrm{U}$ & & Traps \\
\hline Sciurus variegatoides & A & A & $\mathrm{C}$ & Seen \\
\hline Sciurus granatensis & A & $\mathrm{U}$ & & Seen \\
\hline Coendou mexicanus & $\mathrm{R}$ & $\mathrm{R}$ & & Seen \\
\hline Agouti paca & $\mathrm{U}$ & & & Tracks \\
\hline Dasyprocta punctata & $\mathrm{C}$ & $\mathrm{U}$ & & Seen \\
\hline Pecari tajacu & $\mathrm{C}$ & & & Seen/tracks \\
\hline
\end{tabular}

1. Abundance: $\mathbf{A}=$ Abundant species recorded (observed and/or captured) one or more times on at least $80 \%$ of the visits to the site. $\mathbf{C}=$ Common species recorded on 40 to $80 \%$ of visits. $\mathbf{U}=$ Uncommon species recorded on 10 to $40 \%$ of visits. $\mathbf{R}=$ Rare species recorded on fewer than $10 \%$ of visits. Visit to each site includes trapping and walking transects methods.

the small fragment. In contrast, the collared peccary was common in the continuous forest, but absent in both forest fragments. The two species of mice P. mexicanus and Oryzomys alfaroi, were abundant and rare respectively where they were present (Table 1).

Fragmentation effects on seed-predation: Unexpectedly, overall seed-predation in the two forest fragments and continuous forests did not differ statistically when considering all seeds. However, there was a trend of higher seed-predation in continuous forest $(\mathrm{F}=2.73$, d.f. $=2.2, p=0.077$; Fig. 1). Comparing both forest fragments, seed-predation was not statistically different. As expected, more seeds in control plots were preyed upon than seeds in enclosure plots. This applied to all seeds combined as well as individual species $(\mathrm{F}=61.19$, d.f. $=1.42, \mathrm{p}<0.001)$.
Considering each seed species, trends of seed-predation in both the continuous forest and the large fragments were similar in most of the experimental periods (Fig. 2 to 5). However, seed-predation was higher in the continuous forest when compared to the small fragment in only four of the eight experimental periods. Predation of $O$. valeriana seeds was higher in the continuous forest than the small fragment only in the first fruiting season $(\mathrm{F}=$ 8.66 d.f. $=2.30, \mathrm{p}=0.001$, Fig. 2), seeds of $O$. whitei during its first studied fruiting season $(\mathrm{F}=7.94$, d.f. $=2.30, \mathrm{p}=0.02$, Fig. 3$)$ and seeds of $P$. costaricensis during both studied fruiting seasons of this species $(\mathrm{F}=16.54$, d.f. $=2.30$, $\mathrm{p}<0.001$ and $\mathrm{F}=24.13$, d.f. $=2.30, \mathrm{p}<0.001$, Fig. 4). Seed-predation of $P$. costaricensis was similar in the continuous forest and the large fragment. 


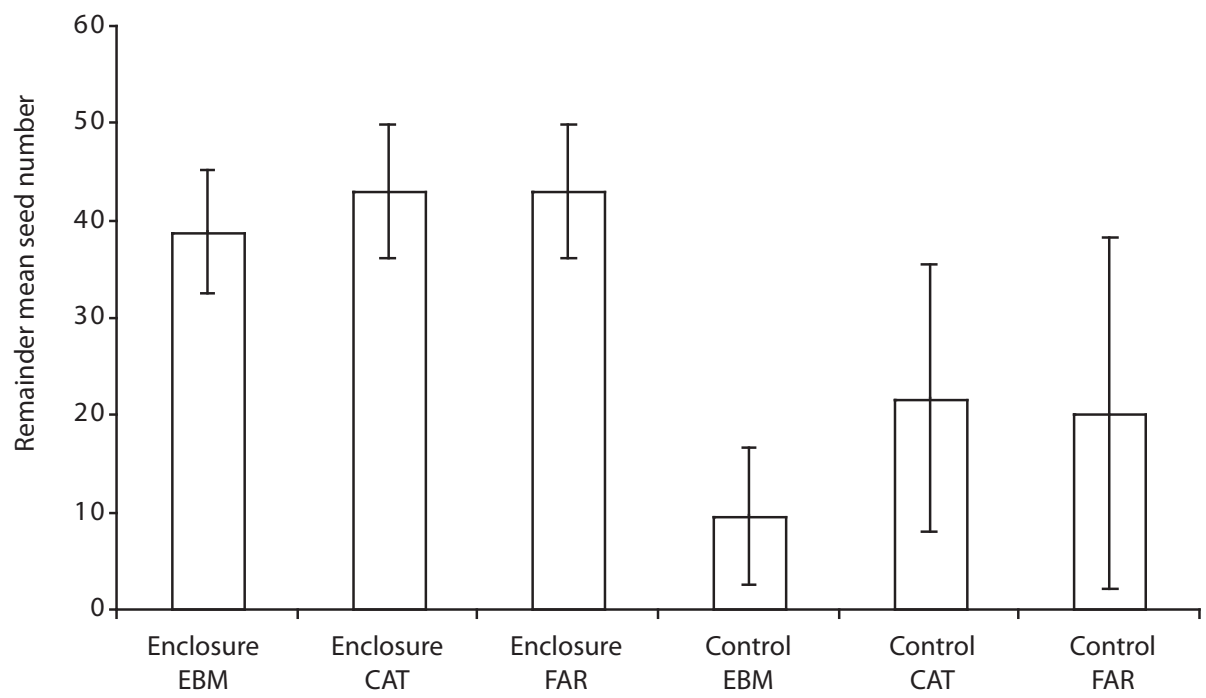

Fig. 1. Mean number of surviving seeds considering the four species in each study site and condition (24 plots per condition, between six to nine seeds in each one). Vertical lines are standard deviations.

Seed-predation of $B$. colombiana was lower in the large fragment compared to the small fragment during the two studied fruiting seasons $(\mathrm{F}=10.99$, d.f. $=2.30, \mathrm{p}<0.001$, and $\mathrm{F}=16.02$, d.f. $=2.30, \mathrm{p}<0.001$, Fig. 5).

Temporal variation of seed predation at species level: Two of the four species of seeds, $O$. valeriana and $O$. whitei, were consumed more during their respective second experimental periods (Fig. 2 and 3). However, $P$. costaricensis and $B$. colombiana seeds were consumed similarly during their respective first and second experimental periods. The seed-predation intensity was lower in the small fragment than in the other two sites in the case of $P$. costaricensis, and was higher in the small fragment than in the other two sites in the case of B. colombiana (Fig. 4 and 5).

\section{DISCUSSION}

This study is the first to evaluate seedpredation by mammals among fragmented and continuous Premontane Tropical Moist forests, and one of the few studies that considers a very small size (20 ha) fragment (Galetti et al. 2003,
Fleury and Galetti 2004). In adition to studying small size fragments, results have shown that continuous forest and a relative large fragment (350 ha) of forest have similar numbers of mammalian seed predators. This finding helps explain similar levels of seed-predation in both sites. Although two mammal species, the pygmy rice mouse (O. fulvescens) and the prehensile-tailed porcupine (C. mexicanus), were not recorded in the continuous forest, but were present in fragments, both have been recorded in the continuous site (Hayes and LaVal 1989, Timm and LaVal 2000). This supports the prediction that continuous forest and larger fragmented sites will have similar species composition of seed predators.

Most of the seed-predator mammals found were small-sized species (mice). Their size apears to makes them more tolerant to diminished forested area (Didham et al. 1998, Chiarello 1999, Fleury and Galetti 2006). Following this perspective, mammals that were not present in fragments are mainly arboreal, and/or bigger species, like pacas (Agouti paca) or collared peccaries (P. tajacu) (more examples in Appendix 1). With respect to 

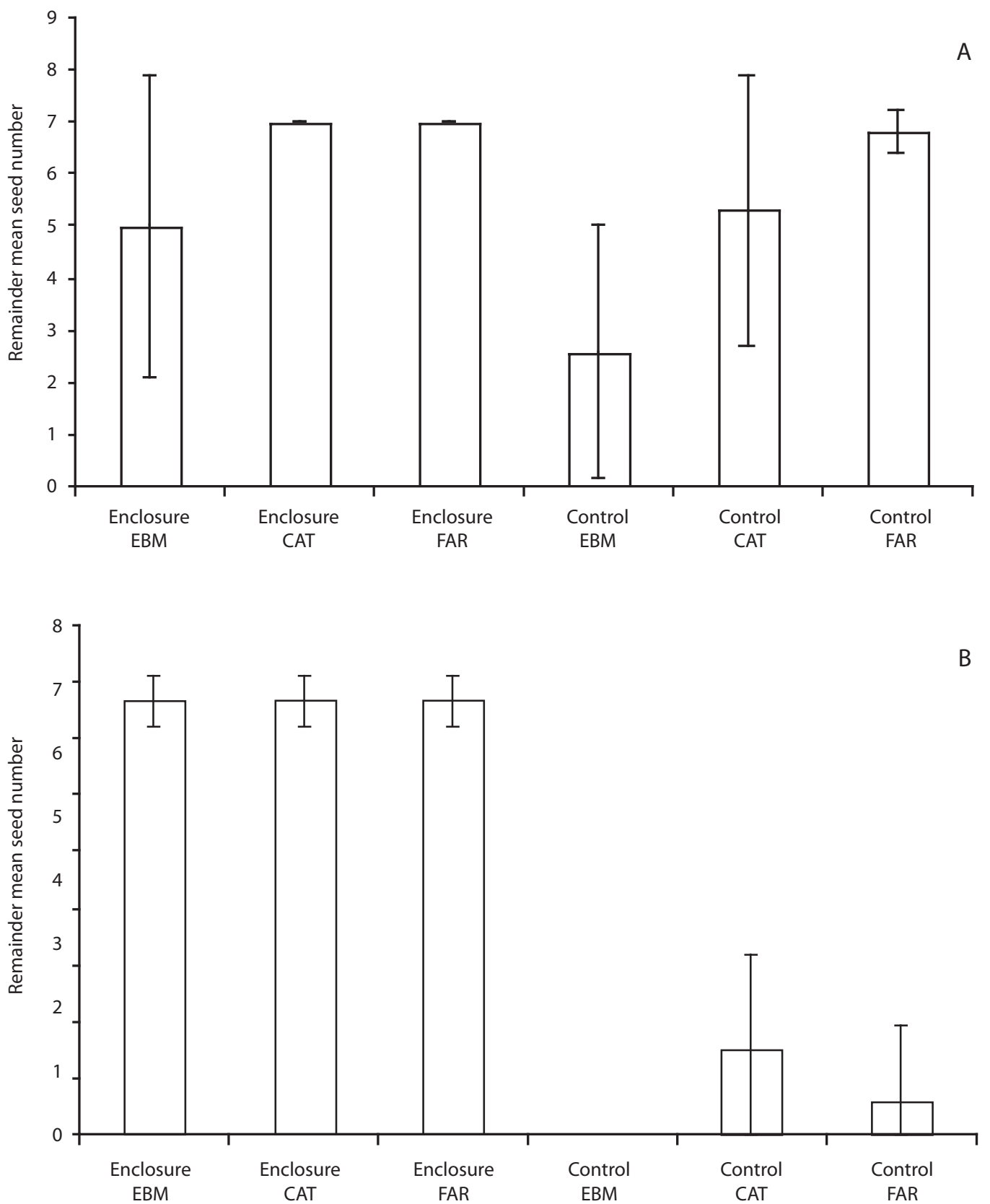

Fig. 2. A. Mean number of surviving Ocotea valeriana seeds in enclosures and open plots. Continuous forest (EBM) and forests fragments (CAT and FAR) in Monteverde, in April-May 2000. B. During April 2001. Vertical lines are standard deviations. 

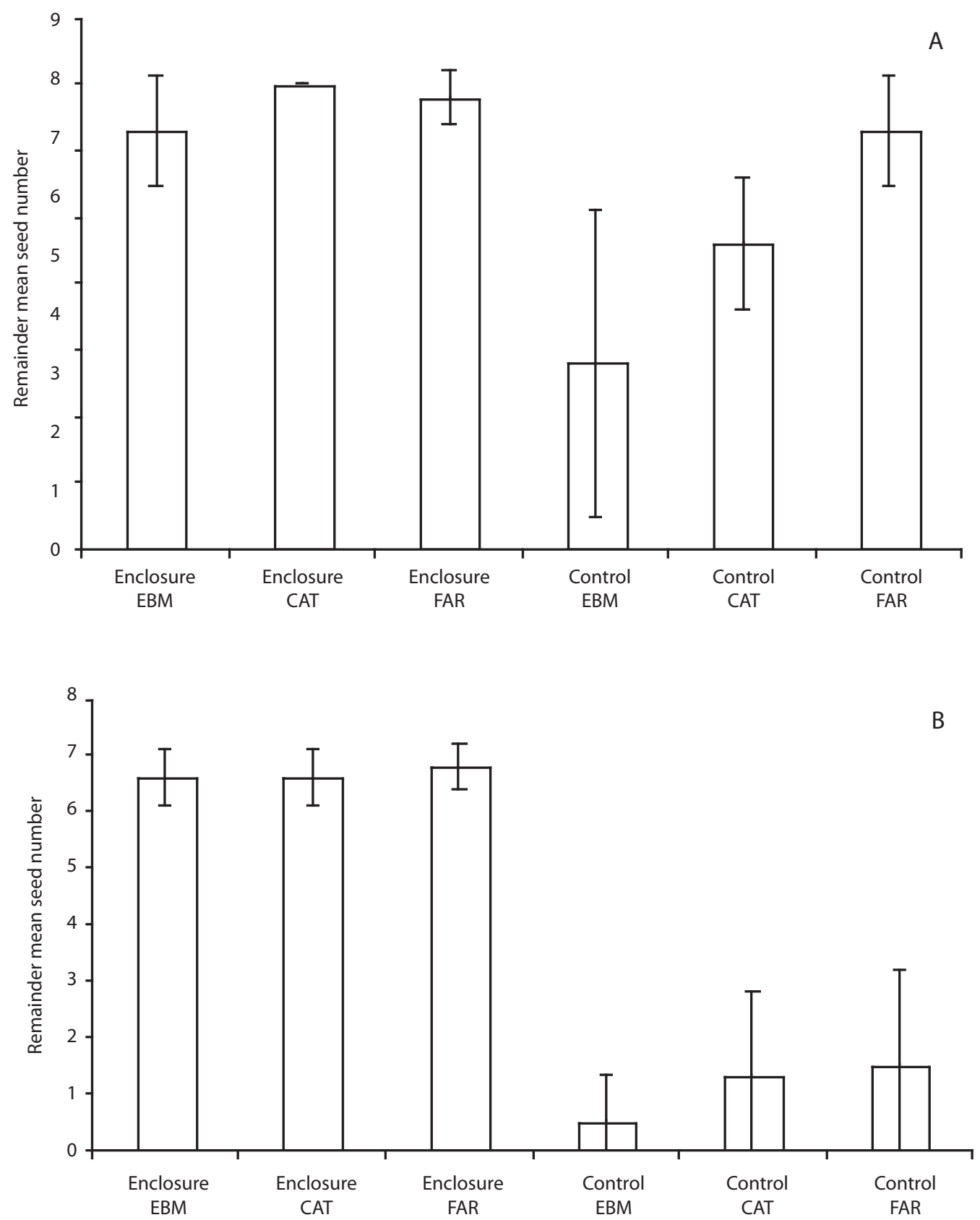

Fig. 3. A. Mean number of surviving Ocotea whitei seeds in enclosures and open plots. Continuous forest (EBM) and forests fragments (CAT and FAR) in Monteverde, in July 2000. B. During June-July 2001. Vertical lines are standard deviations. 

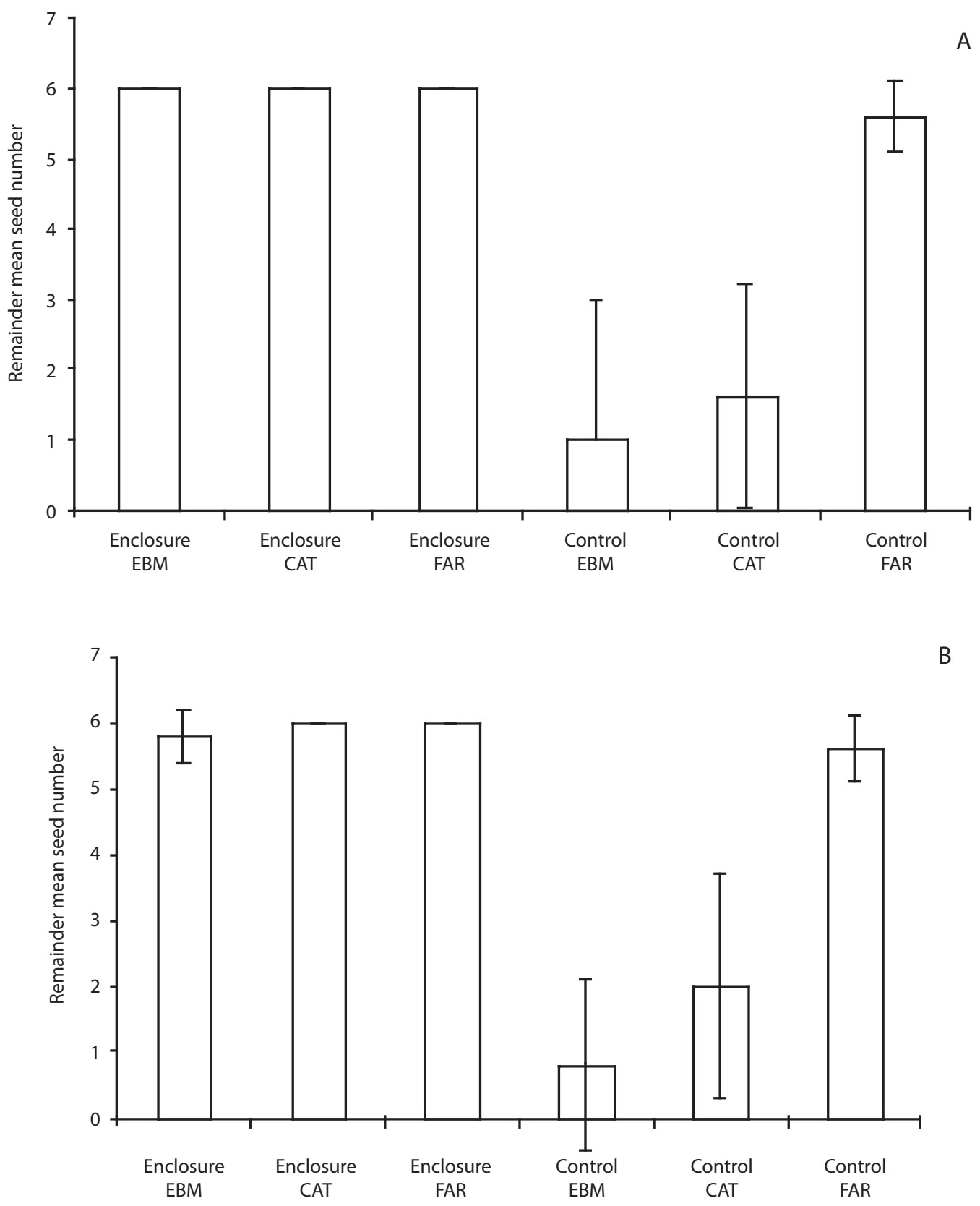

Fig. 4. A. Mean number of surviving Panopsis costaricensis seeds in enclosures and open plots. Continuous forest (EBM) and forests fragments (CAT and FAR) in Monteverde, in September 2001. B. During September 2002. Vertical lines are standard deviations. 

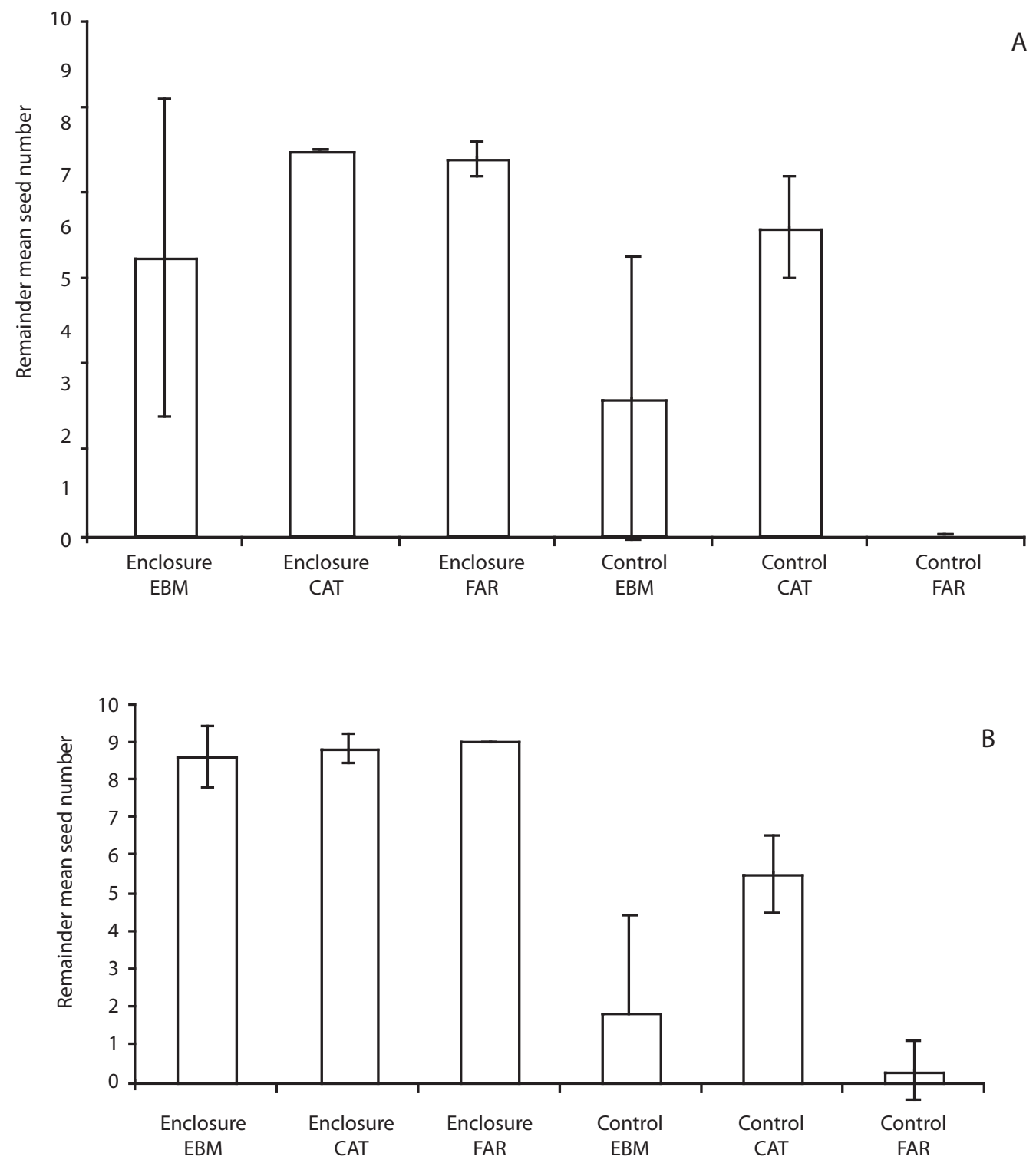

Fig. 5. A. Mean number of surviving Billia colombiana seeds in enclosures and open plots. Continuous forest (EBM) and forests fragments (CAT and FAR) in Monteverde, in October 2000. B. During October 2001. Vertical lines are standard deviations.

seed predation, the absence of large mammals in small fragments can be off-set by the relative higher abundance of specialized small seed predators. For example Desmarest's spiny pocket mouse ( $H$. desmarestianus), is a specialized seed-predator: its higher abundance in Monteverde fragments likely implies higher rates of seed predation, as other studies have found in temperate ecosystems in which a specialized seed predator is present (Donoso et al. 2003) as well as in tropical rain forest (Fleury and Galetti 2006). 
The higher abundance of $H$. desmarestianus in forest fragments could be caused by two phenomena. First, one is its fidelity to forested areas, not been able to use pastures or nearby houses, as the abundant rodent $P$. mexicanus does. Specially young individuals of $H$. desmarestianus may fail to disperse because they are surrounded by inimical habitats. Second, survivorship of mice may be relatively high because of the absence, or scarcity of carnivores. As a result, small mammals such as $H$. desmarestianus suffer an effect of overcrowding without opportunities to disperse to other forest patches. This high density exacerbates their effect as seed-predators in small forest fragments (Fleury and Galetti 2006, Dirzo et al. 2007).

The lower abundance in the forest fragments of bigger sized rodents (D. punctata and $S$. granatensis) and other larger-sized mammalian predators ( $P$. tajacu), seems to be strongly related with the consistent pattern of higher predation on $P$. costaricensis seeds in the continuous forest. The $P$. costaricensis seeds are large enough and may escape from predation by smaller rodents (Dirzo et al. 2007) more abundant in fragments. These seeds are difficult to break and mostly D. punctata is able to gnaw through their hard outer rind to eat them. On the other hand, Ocotea spp. seeds that have relative soft endocarp, experienced higher predation in the fragments than $P$. costaricensis seeds.

The pattern of predation observed in $B$. colombiana seeds in the smaller fragment, contrasts strongly with the other species of seeds: predation on $B$. colombiana seeds was much higher. This result can perhaps be explained by the complete absence of adult trees of B. colombiana in that particular fragment. Experimental seeds of this species comprised a different and atractive food. For the other species of seeds studied, experimental seeds encountered on the ground were just more of the same type of food produced by trees in each site. Seed-predators did not eat them apparently because they were already satiated by the naturally occurring seeds in that site. But the B. colombiana seeds in the small fragment were a novel type of food, that was attractive to at least some of the small mammals present (Janzen 1971, Wright 2003, Xiao et al. 2004).

Among the natural factors affecting the production and fate of seeds are climate, flower composition and behavior of visitors to flowers, herbivory, and seed dispersers (Jara 1996, Xiao et al. 2004). If all of these factors are changing with time in fragmented forests, as well as the intensity of seed-predation, recruitment and reproduction of plants in these forest fragments will be difficult to predict. Long-term studies information are needed to understand the fate of some plant populations in altered landscapes.

\section{ACKNOWLEDGMENTS}

I thank Luisa Moreno, Frank Joyce, Gerardo Ceballos, Rodolfo Dirzo and Ignacio Méndez for their guidance and logistical support. Two anonymous reviewers helped to improved this paper. Frank Joyce edited the English and corrected several details of the first submission. Allison Deines, Mauricio García, Edgardo Arévalo, Yuber Rodríguez, Eladio Cruz and Gladys Valencia provided valuable help during the fieldwork. Thank to Marvin Hidalgo, Mariano Arguedas, Eduardo Arguedas and Franklin Arce for permissions to work in their properties. Thank to Oscar Brenes, Marvin Hidalgo, Wally VanSikle, Barbara Lewis and Johnny Rosales for financial support. The Institute of Ecology of the National Autonomous University of Mexico (UNAM), Idea Wild, Monteverde Biological Station (EBM), Organization for Tropical Studies (OTS), WWF-Central America through the Mesoamerican Biological Corridor Program (CBM), and Monteverde Conservation League (MCL) provided financial and logistical support.

\section{RESUMEN}

Pocos estudios han evaluado la depredación de semillas en ambientes fragmentados, en éstos la menor diversidad de especies debe estar modificando las interacciones 
ecológicas. Se investigó la remoción de semillas por mamíferos en un bosque continuo y dos fragmentos en Monteverde, Costa Rica. Se registró la composición de mamíferos en cada sitio durante 16 meses y se observó la remoción de semillas experimentales del suelo del bosque. Se utilizó semillas de cuatro especies de árboles: Ocotea valeriana, Ocotea whitei, Panopsis costaricensis y Billia colombiana, durante dos periodos anuales de fructificación cada una. Los resultados indican una composición de depredadores de semillas similar entre el bosque continuo y el fragmento de 350 ha, más diversos que el fragmento de 20 ha, en el cual el especialista en semillas Heteromys desmarestianus fue más abundante. La depredación de semillas entre el bosque continuo y los fragmentos no fue estadísticamente diferente al considerar todas las especies de semillas, debido a la mayor abundancia de depredadores pequeños, que pudo compensar la ausencia de depredadores de talla mediana y grande que sí están presentes en el bosque continuo. La depredación sobre semillas fue mayor cuando la oferta de semillas no experimentales fue menor, indicando que la saciedad de los depredadores puede estar determinando la remoción de semillas en fragmentos, más que la riqueza o abundancia de especies depredadoras.

Palabras clave: remoción de semillas, depredadores de semillas, fragmentación, saciedad de depredadores.

\section{REFERENCES}

Aranda, M. 1981. Rastros de los mamíferos silvestres de México. Instituto Nacional de Investigaciones sobre Recursos Bióticos. Xalapa, Veracruz, Mexico.

Cascante, A. 1998. Efecto de la fragmentación del bosque seco tropical sobre el éxito reproductivo de una especie de árbol maderable Samanea saman (Mimosaceae). Tesis de Bachillerato. Escuela de Biología, Universidad de Costa Rica, San Jose, Costa Rica.

Castro, K.L. 1998. Germination studies on two tropical species, Alnus acuminata arguta (Schlechtendal) Furlow and Pithecellobium saman (Jacq.) Benth. Master of Science Thesis, University of Alberta, Edmonton, Alberta, Canada.

Chiarello, A.G. 1999. Effects of fragmentation of the Atlantic forest on mammal communities in southeastern Brazil. Biol. Conserv. 89: 71-82.

Didham, R.K., P.M. Hammond, J.H. Lawton, P. Eggleton \& N.E. Stork. 1998. Beetle species responses to tropical forest fragmentation. Ecol. Monogr. 68: 295-323.

Dirzo, R. \& A. Miranda. 1991. Altered patterns of herbivory and diversity in the forest understory, a case study of the possible consequences of contemporary defaunation, p. 273 - 287. In: P.W. Price, T.M. Lewinsohn, G. Wilson Fernandes \& W.W. Benson (eds.). Plant Animal Interactions, Evolutionary Ecology in Tropical and Temperate Regions. Wiley, New York, USA.

Dirzo, R., E. Mendoza \& P. Ortiz. 2007. Size - related differential seed predation in a heavily defaunated Neotropical rain forest. Biotropica 39: 355-362.

Donoso, D.S., A.A. Grez \& J.A. Simonetti. 2003. Effects of forest fragmentation on the granivory of different sized seeds. Biol. Conserv. 115: 63-70.

Ferreira, L.V. \& W.F. Laurance. 1997. Effects of forest fragmentation on mortality and damage of selected trees in Central Amazonia. Conserv. Biol. 11: $797-$ 801 .

Fleury, M. \& M. Galetti. 2004. Effects of microhabitat on palm seed predation in two forest fragments in southeast Brazil. Acta Oecol. 26: 179-184.

Fleury, M. \& M. Galetti. 2006. Forest fragment size and microhabitat effects on palm seed predation. Biol. Conserv. 131: 1-13.

Galetti, M., C.P. Alves-Costa \& E. Cazetta. 2003. Effects of forest fragmentation, anthropogenic edges and fruit color on the consumption of ornithocoric fruits. Biol. Conserv. 111: 269-273.

Guindon, C.F. 1997. The importance of forest fragments to the maintenance of regional biodiversity surrounding a tropical montane reserve, Costa Rica. Doctor Thesis, Yale University, New Haven, Connecticut, USA.

Haber, W.A., W. Zuchowski \& E. Bello. 1996. An introduction to cloud forest trees: Monteverde, Costa Rica. La Nación. San Jose, Costa Rica.

Hayes, M. \& R.K. LaVal. 1989. The mammals of Monteverde, Costa Rica. Centro Científico Tropical, San José. Costa Rica.

Janzen, D. 1971. Seed predation by animals. Annu. Rev. Ecol. Syst. 2: 465-492.

Jara, L.F. 1996. Biología de semillas forestales. Centro Agronómico Tropical de Investigación y Enseñanza CATIE, Turrialba, Costa Rica.

Kitamura, S. \& T. Yumoto. 2002. Interactions between fleshy fruits and frugivores in a tropical seasonal forest in Thailand. Oecologia 133: 559-572. 
Laurence, W.F. \& R.O. Bierregaard. 1997. Tropical Forest Remnants: Ecology, Management and Conservation of Fragmented Communities. University of Chicago, Chicago, USA.

Murcia, C. 1995. Edge effects in fragmented forest, implications for conservation. Trends Ecol. Evol. 10: 58-62.

Nadkarni, N. \& N.T. Wheelwright. 2000. Monteverde: ecology and conservation of a tropical cloud forest. Oxford University, New York, USA.

Phillips, O.L. 1997. The changing ecology of tropical forests. Biodivers. Conserv. 6: 291-311.

Rao, M., J. Terborgh \& P. Nuñez. 2001. Increased herbivory in forest isolates: implications for plant community structure and composition. Conserv. Biol. 15: 624-633.

Reid, F.A. 1997. A field guide to the mammals of Central America and Southeast Mexico. Oxford University, New York, USA.

Roldán A.I. \& J.A. Simonetti. 2001. Plant-mammal interactions in tropical Bolivian forests with different hunting pressures. Conserv. Biol. 15: 617-623.

Ruiz, B. 2003. Impacto de la fragmentación sobre los factores del ambiente físico y los patrones de herbivoría en plantas de la selva de los Tuxtlas, Veracruz. Tesis de Bachillerato. Facultad de Ciencias, UNAM, Mexico DF, Mexico.

Sánchez-Azofiefa, G.A., G.C. Daily, A.S.P. Pfaff \& C. Busch. 2003. Integrity and isolation of Costa Rica's national parks and biological reserves: examining the dynamics of land-cover change. Biol. Conserv. 109: 123-135.
Saunders, D.A., R.J. Hobbs \& C.R. Margules. 1991. Biological consequences of ecosystems fragmentation: a review. Conserv. Biol. 5: 18-32.

Serrano, J.A. \& I. Vargas. 1995. Statgraphics 2.1. Facultad de Ciencias, UNAM, Mexico DF, Mexico.

Sokal, R.S. \& F.J. Rohlf. 2003. Biometry. W.H. Freeman. New York, USA.

Terborgh, J. \& J. Wright. 1994. Effects of mammalian herbivores on plant recruitment in two neotropical forests. Ecology 75: 1829-1833.

Timm, R.M. \& R.K. LaVal. 2000. Mammals. In: Nadkarni, N. \& N. Wheelwright (eds.) Monteverde: ecology and conservation of a tropical cloud forest. Oxford University, New Cork,USA.

Tosi, J.A. 1969. Mapa ecológico, Republica de Costa Rica: según la clasificación de zonas de vida del mundo de L.R. Holdridge. Centro Científico Tropical. San Jose. Costa Rica.

Wright, S.J. 2003. The myriad consequences of hunting for vertebrates and plants in tropical forests. Perspect. Plant Ecol. 6: 73-86.

Wright, S.J. 2005. Tropical forests in a changing environment. Trends Ecol. Evol. 20: 553-560.

Wright, S.J., K.E. Stoner, N. Beckman, R.T. Corlett, R. Dirzo, H.C. Muller-Landau, G.Nuñez-Iturri, C.A. Peres \& B.C. Wang. 2007. The plight of large animals in tropical forests and the consequences for plant regeneration. Biotropica 39: 289-291.

Xiao, Z., Z. Zhang \& Y. Wang. 2004. Impacts of scatterhoarding rodents on restoration of oil tea Camelia oleifera in fragmented forest. Forest Ecol. Manag. 196: 405-412. 


\section{APPENDIX 1}

All the mammal species found in the three study sites in Monteverde, Costa Rica

\begin{tabular}{|c|c|c|c|c|}
\hline Species & $\begin{array}{l}\text { Continuous } \\
\text { forest }\end{array}$ & $\begin{array}{l}\text { Large fragment } \\
\text { CAT }\end{array}$ & $\begin{array}{c}\text { Small fragment } \\
\text { FAR }\end{array}$ & $\begin{array}{l}\text { Presence } \\
\text { evidence }\end{array}$ \\
\hline Peromyscus mexicanus & $\mathrm{x}$ & $\mathrm{x}$ & $\mathrm{x}$ & Traps \\
\hline Scotinomys teguina & $\mathrm{x}$ & & & Traps \\
\hline Oryzomys albigularis & $\mathrm{x}$ & & & Traps \\
\hline Oryzomys alfaroi (group) & $\mathrm{x}$ & $\mathrm{x}$ & & Traps \\
\hline Oligoryzomys fulvescens & $\mathrm{x}$ & & & Traps \\
\hline Nyctomys sumichrasti & $\mathrm{x}$ & & & Traps \\
\hline Tylomys watsoni & $\mathrm{x}$ & & & Traps \\
\hline Heteromys desmarestianus & $\mathrm{x}$ & $\mathrm{x}$ & $\mathrm{x}$ & Traps \\
\hline Reithrodontomys gracilis & $\mathrm{x}$ & $\mathrm{x}$ & & Traps \\
\hline Sciurus variegatoides & $\mathrm{x}$ & $\mathrm{x}$ & $\mathrm{x}$ & Seen \\
\hline Sciurus granatensis & $\mathrm{x}$ & $\mathrm{x}$ & & Seen \\
\hline Coendou mexicanus & $\mathrm{x}$ & $\mathrm{x}$ & & Seen \\
\hline Agouti paca & $\mathrm{x}$ & & & Tracks \\
\hline Dasyprocta punctata & $\mathrm{x}$ & $\mathrm{x}$ & & Seen \\
\hline Didelphis marsupialis & $\mathrm{x}$ & & & Seen/tracks \\
\hline Choloepus hoffmani & $\mathrm{x}$ & $\mathrm{x}$ & $\mathrm{x}$ & Seen \\
\hline Dasypus novemcintus & $\mathrm{x}$ & & & Seen/tracks \\
\hline Cebus capucinus & $\mathrm{x}$ & $\mathrm{x}$ & & Seen \\
\hline Ateles geoffroyi & $\mathrm{x}$ & & & Seen/listened \\
\hline Alouatta palliata & $\mathrm{x}$ & & & Seen \\
\hline Urocyon cinereoargenteus & $\mathrm{x}$ & $\mathrm{x}$ & & Seen \\
\hline Nasua narica & $\mathrm{x}$ & $\mathrm{x}$ & & Seen \\
\hline Procyon lotor & $\mathrm{x}$ & & & Tracks \\
\hline Mustela frenata & $\mathrm{x}$ & $\mathrm{x}$ & $\mathrm{x}$ & Seen/traps \\
\hline Potos flavus & $\mathrm{x}$ & $\mathrm{x}$ & & Seen/listened \\
\hline Puma concolor & $\mathrm{x}$ & & & Tracks \\
\hline Herpailurus yaguaroundi & $\mathrm{x}$ & & & Seen \\
\hline Leopardus pardalis & $\mathrm{x}$ & & & Tracks \\
\hline Leopardus wieddii & $\mathrm{x}$ & & & Tracks \\
\hline Pecari tajacu & & $\mathrm{x}$ & & Seen/tracks \\
\hline Mazama americana & $\mathrm{x}$ & & & Tracks \\
\hline
\end{tabular}

